\title{
LAS FIESTAS CÍVICAS DEL TRIENIO PROGRESISTA (1840-1843): PROGRESISTAS ENFRENTADOS Y DESAFÍO A LA REGENCIA
}

\section{THE CIVIC FESTIVALS OF THE PROGRESSIVE TRIENNIUM (1840-1843): PROGRESSIVES OPPOSITE AND CHALLENGE TO THE REGENCY}

\author{
Jordi Roca Vernet \\ Universitat de Barcelona - Universitat Rovira i Virgili, Tarragona, España \\ ORCID: orcid.org/0000-0002-0148-257X
}

Recibido el 19-2-2017 y aceptado el 23-10-2017

\begin{abstract}
Resumen: Las fiestas cívicas del Trienio Progresista (1840-1843) muestran cómo el progresismo radical construyó no solo una alternativa política diferenciada del progresismo partidario de Baldomero Espartero y del progresismo de orden, sino que articuló una cultura subversiva y reivindicativa en la que confluyeron distintos grupos sociales y alternativas políticas. El progresismo radical se enfrentó al progresismo y al moderantismo de notables, proponiendo un modelo basado en la centralidad política del espacio local y una propuesta social democráticamente reformista. Las fiestas demuestran la extensión política y social de aquella alternativa que logró proyectarse en el gobierno de la ciudad de Barcelona y proponer un discurso nacional distinto. La ciudadanía participó y se apropió de unas prácticas culturales y de unos símbolos que configuraron una identidad progresista diferenciada de otros progresismos.
\end{abstract}

Palabras clave: Liberalismo Progresista, Progresismo Radical, Progresismo Popular, Fiestas Cívicas, Soberanía Nacional, Ciudad, Obreros.

Abstract: The civic festivals of the Progressive Triennium (1840-1843) show how radical progressivism constructed not only a political alternative differentiated from party progressive and the popular progressive, but also articulated a subversive and vindicating culture in which different social groups converged and political alternatives. Radical progressive faced progressive and the 
moderate parties formed by notables, proposing a model based on the political centrality of the local space and a democratically reformist social proposal. The civic ceremonies demonstrate the political and social extension of that alternative which managed to project itself into the government of the city of Barcelona and propose a distinct national discourse. Citizens participated and appropriated cultural practices and symbols that shaped a progressivism identity differentiated from other progressivisms.

Keywords: Progressive Liberalism, Radical Progressivism, Popular Progressivism, Civic Celebrations, National Sovereignty, City, Workers. 


\section{Introducción}

El progresismo radical triunfó en Barcelona el verano de 1843, pero su proyecto político no obtuvo el apoyo de la mayoría en las Cortes. A menudo se ha simplificado aquel proyecto vinculándolo a los intereses de la burguesía industrial, que había defendido una parte significativa de los diputados catalanes ${ }^{1}$. El progresismo radical fue industrialista, pero eso no significa que se identificara con los intereses de los fabricantes sino que propuso un proyecto político que impulsaba de nuevo la Revolución Liberal. Así, en algunas de las principales ciudades españolas emergió un progresismo radical y popular que intentaba democratizar el régimen liberal. Barcelona lideró aquel progresismo, que alcanzó su cenit aquel verano con la revolución centralista convocada por una Junta Central cuando el gobierno ya había dispuesto la apertura de las Cortes. Aquella iniciativa desafiaba la legalidad vigente al abrir de nuevo el proceso revolucionario, lo que permitiría modificar el marco constitucional redefiniendo el papel de la Corona en la nación liberal.

Esta investigación, a través del análisis de las fiestas políticas del Trienio Progresista (1840-1843), demostrará que en este periodo se formuló una alternativa liberal progresista radical que desafió al progresismo gubernamental y a la monarquía. Las fiestas políticas o cívicas desplegaron un universo simbólico que no era compartido por los grupos de notables progresistas de la cámara parlamentaria ni por la mayoría del progresismo popular esparterista, y revelaron un modelo político ampliamente participativo, socialmente reformista e inconformista con la capacidad política de la monarquía. Las fiestas cívicas se convirtieron en una rememoración permanente del insurreccionalismo frente a los gobiernos liberales moderados, percibidos como despóticos, lo que significó deslegitimar al régimen liberal monárquico y alejó la representatividad nacional de la práctica parlamentaria, reforzando la descentralización de la representación nacional en el marco local y provincial. Las fiestas corroboraron la aspiración del progresismo radical de ampliar su base social entre las clases populares con el objetivo de proponer una alternativa nacional, sustentada en las ciudades revolucionarias del arco mediterráneo, de Castilla y de Galicia, que desafiara el liderazgo político del centro y de la Corona, y que desautorizara a las Cortes como única expresión de la soberanía nacional.

${ }^{1}$ Fuster, 2008. 
El progresismo radical barcelonés aglutinó en torno a él una parte significativa del progresismo catalán y fue socialmente hegemónico durante el Trienio, pues consiguió aunar el apoyo del mundo popular - representado mayoritariamente por los trabajadores de oficio-y de las clases medias alrededor de una alternativa política reformista ${ }^{2}$ que denostaba cualquier acuerdo o pacto con el liberalismo moderado y que se identificaba plenamente con el desarrollo de la Revolución Liberal. El análisis de los símbolos asociado a las fiestas demuestra que la cultura del progresismo estuvo determinada por la etapa represora del capitán general de Cataluña, el barón de Meer (1837-1839), conocida como la dictadura de Meer. En aquellos años el gobierno liberal aplicó el estado de excepción y suspendió las garantías constitucionales, y para ello contó con el aplauso de los principales fabricantes de Barcelona ${ }^{3}$. Aquella situación se había producido antes a raíz de las bullangas de 1835, y después durante el Trienio Progresista, lo que reforzó la convicción de que la intervención gubernamental con el ejército impedía sistemáticamente el desarrollo revolucionario del liberalismo. Desde los años del Trienio Liberal (1820-1823) se habían producido enfrentamientos entre el liberalismo revolucionario más popular del espacio local barcelonés, que a menudo arrastraba el provincial, y el gobierno nacional, lo que reforzó la percepción de que el gobierno usaba el ejército para acotar la vía revolucionaria y alimentaba, sin quererlo, las propuestas que pretendían minimizar el papel del gobierno y aumentar la capacidad política de los cuerpos políticos locales y provinciales.

Las fiestas cívicas en Barcelona se distinguieron de las del resto de ciudades españolas, en particular de las de Madrid - las mejor estudiadas - , por su carácter rupturista con respecto a las fiestas políticas precedentes, por el poco recorrido de las fiestas cívicas designadas como nacionales por la cámara parlamentaria, y por la extinta continuidad de aquellas fiestas cívicas en etapas posteriores. Por otro lado, las fiestas cívicas se convirtieron en un espacio de representación política para el naciente obrerismo, que celebró las fiestas «democráticas», convirtiéndose en una práctica democratizadora que fomentaba nuevas formas de solidaridad social. Así pues, como afirma Jürgen Osterhammel ${ }^{4}$, la democracia se construyó desde abajo, transformando las costumbres en

\footnotetext{
2 Barnosell, 2011, pp. 96-99.

3 Risques, 1995.

${ }^{4}$ Osterhammel, 2015, p. 855.
} 
derechos. Los espacios y asociaciones en los que se representó la interacción de ciudadanos sin depender de su condición social fueron las auténticas escuelas de democratización. La alternativa progresista radical, definida como democrática y local, consiguió un amplio consenso popular porque fue capaz de proyectarse como una opción auténticamente rupturista con el pasado, y fue capaz de combinar una cultura popular subversiva con un proyecto revolucionario que despertaba grandes expectativas democratizadoras.

\section{Las fiestas cívicas y la cultura liberal progresista}

En las últimas dos décadas la historiografía francesa ${ }^{5}$ ha retomado los estudios sobre la fiesta revolucionaria desde una nueva perspectiva basada en el análisis cultural de la política haciendo hincapié en la fiesta como ritual político, como forma de legitimidad de la autoridad y como parte del proceso de construcción de identidades colectivas. La historiografía sobre la fiesta se ha proyectado hacia las expresiones de resistencia a esta, definiéndolas como anti-fiesta o contra-fiesta, e identificándolas como formas precursoras de la manifestación en función de su relación con la prensa, los movimientos sociales o el Estado. De todos modos, la fiesta ha alcanzado mayor interés en Francia cuando se ha interpretado como una forma de pedagogía política basada en ritos de representación de los sucesivos regímenes. En lengua castellana, el impacto de la historiografía francesa sobre la fiesta se ha producido mayoritariamente entre las historiografías argentina y mexicana, que se han ocupado del estudio de la fiesta durante la primera mitad del siglo XIX con el fin de analizar las continuidades, los nuevos contextos y la resignificación que se derivó de ellos. Para el caso argentino los trabajos de Francisco Reyes ${ }^{6}$ y María Lía Munilla Lacasa ${ }^{7}$ han permitido sistematizar y organizar el estudio de las fiestas, convirtiéndolas en un lugar de participación, comunicación y negociación de valores e imaginarios, mientras en el caso mexicano los estudios de Silke Hensel ${ }^{8}$ y Katrina Dircksen ${ }^{9}$ han enfatizado cómo las liturgias revolucionarias se

\footnotetext{
5 Ihl, 1996, y Hazareesingh, 2004.

${ }^{6}$ Reyes, 2015.

7 Munilla, 2013.

8 Hensel, 2011.

9 Dircksen, 2011.
} 
adaptaron a cada entorno para evitar desarrollos potencialmente subversivos y cómo la incorporación del discurso liberal generó nuevos contextos que resignificaron los ceremoniales tradicionales.

El hispanismo francés fue pionero en el estudio de la fiesta política a finales del siglo pasado y principios del actual ${ }^{10}$, y coetáneamente aparecieron en España algunos estudios de caso relevantes dedicados a la fiesta $^{11}$. En la actualidad la historiografía sobre la fiesta vive un nuevo auge en España a través, por un lado, del estudio de los ceremoniales ${ }^{12}$ y de los rituales como expresiones de valores políticos ${ }^{13}$, constitutivos de las culturas políticas ${ }^{14} \mathrm{o}$ de las identidades políticas ${ }^{15}$, poniendo énfasis en sus transformaciones y resignificaciones en los tiempos largos ${ }^{16}$; por otro lado, fijándose en las representaciones iconográficas que conformaban una imagen del régimen liberal ${ }^{17}$. Finalmente, recientemente han sido estudiadas las fiestas cívicas durante la Revolución Liberal, centrándose en su aspecto nacionalizador ${ }^{18}$ y en las estrategias empleadas para fomentar la popularidad y el entusiasmo popular hacia el régimen libera ${ }^{19}$.

La fiesta cívica durante el Trienio Progresista es interpretada en este artículo como un proceso de construcción cultural del progresismo radical en el que confluyen distintas alternativas políticas, opuestas estas al desarrollo de un régimen liberal incapaz de satisfacer las expectativas generadas y dominado por los grupos de notables. Se aborda la fiesta política desde una perspectiva conmemorativa, centrada en el significado que le otorgaron los distintos progresismos, por lo que deviene más relevante interpretar las fiestas como un elemento determinante de la conformación de la cultura progresista que como un espacio de adhesión y entusiasmo al régimen liberal, de interpretación del ritual como representación del poder o de experiencia social del tiempo basada en la nación y compartida por la ciudadanía.

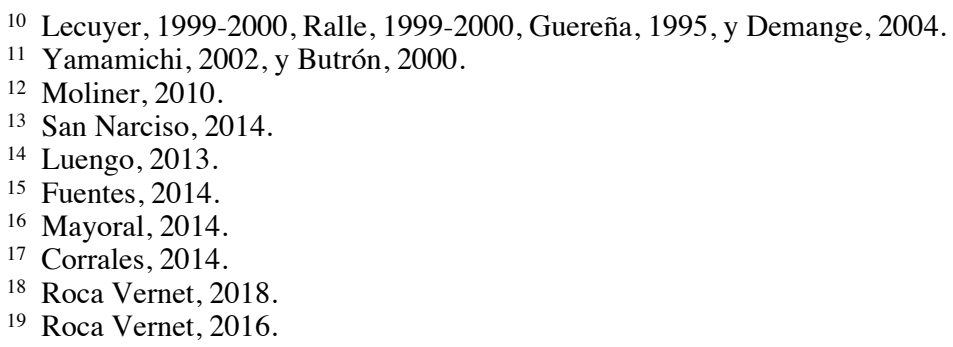


Hasta ahora, la historia del progresismo isabelino se ha centrado casi exclusivamente en un análisis de su expresión parlamentaria y gubernamental y en aproximaciones biográficas de los grandes espadones como Baldomero Espartero. Este último ha sido estudiado en numerosos trabajos, aunque sin duda los más brillantes son los de Adrian Shubert ${ }^{20}$, interesado en los procesos de transmisión y permanencia del culto al general, y los de Luis Garrido ${ }^{21}$, quien aborda cómo la Guerra Carlista (1833-1840) y sobre todo la victoria de Luchana convirtieron al general en el héroe romántico por antonomasia. Por su parte, Pedro Díaz ha demostrado que la imagen del regente Espartero durante el Trienio Progresista acabó siendo asociada a la traición de la revolución de septiembre de 1840 y a la ineficiencia gubernamental, al identificarse con el gobierno, y cómo los moderados lo erigieron como el acicate contra la iglesia y la monarquía, desvaneciéndose todos sus apoyos 22 .

En clave parlamentaria el progresismo isabelino se ha estudiado a través del análisis de su identidad y cultura política, superando las decimonónicas historias sobre el partido. Estos trabajos han subrayado que el progresismo representó «una discontinuidad en la evolución política del siglo» al no ser herederos de los exaltados ni antecesores del liberalismo de la Restauración ${ }^{23}$. La identidad del progresismo ha sido definida por Juan Pan-Montojo por su anglofilia, basada en el modelo de sociedad y sistema político defendido, y por el culto a la soberanía nacional ${ }^{24}$. A pesar de la herencia más o menos revolucionaria, como apunta María Cruz Romeo, el partido progresista surgió como un partido de orden que aspiraba a la participación legal en las estructuras estatales y que quería evolucionar hacia una monarquía parlamentaria para oponerse tanto al radicalismo revolucionario como al carlismo ${ }^{25}$. De acuerdo con Isabel Burdiel, el discurso progresista no se inclina necesariamente por métodos revolucionarios sino que promueve la aceleración de reformas que sitúen la soberanía nacional en el centro del sistema y eviten el recurso de la revolución ${ }^{26}$. También apunta que el progresismo colaboró en otorgar un papel

\footnotetext{
20 Shubert, 2015.

21 Garrido, 2012.

22 Díaz, 2008, p. 213

23 Pan-Montojo, 2006, p. 184.

24 Pan-Montojo, 2006, p. 187.

25 Romeo, 2006, p. 93.

26 Burdiel, 2000, pp. 113-114.
} 
central a la monarquía en el diseño de los regímenes liberales posrevolucionarios y devino a su vez una institución sancionada y legitimada por la soberanía nacional y derivada de la propia revolución ${ }^{27}$.

Los estudios de Romeo fueron pioneros en el estudio de la cultura política progresista a partir del análisis del discurso, donde enfatizaba una resonancia republicana clásica que apelaba a la virtud pública, al interés común y a la crítica al capitalismo especulativo ${ }^{28}$. También se han ocupado de la memoria histórica y narrativa nacional del progresismo, observando cómo se proyecta el derecho insurreccional contra Fernando VII e Isabel II, con lo que el historicismo se erige en una forma de acción revolucionaria ${ }^{29}$. Por otra parte, Rafael Zurita ha abordado los mitos progresistas como generadores de emociones capaces de codificar formas de pensamiento político, y el historicismo como un «eficaz instrumento para legitimar su cultura política y como pedagogía que promoviese la movilización política ${ }^{30} \gg$. Otros estudios, como los de María Sierra, han apuntado que la cultura política es producida por sujetos y discursos combinándose en equilibrios desiguales según el momento histórico ${ }^{31}$, metodología que ha aplicado junto a María Antonia Peña y R. Zurita al progresismo a través del estudio de los discursos de representación ${ }^{32}$. Finalmente, Javier Fernández Sebastián, desde una perspectiva distinta, apunta que los gobiernos progresistas fueron el motor de la transformación de la sociedad española en el plano económico y de las libertades públicas, pero subraya las disensiones y divisiones del partido ${ }^{33}$ consecuencia de su falta de cohesión social, política e ideológica.

Las bases sociales y las propuestas sociopolíticas del progresismo han sido estudiadas por Genís Barnosell ${ }^{34}$, quien afirma que el progresismo en Cataluña consiguió una base social interclasista que no lo distinguía del radicalismo liberal, y obtuvo el apoyo del sindicalismo mediante un lenguaje político de clase más radical que el republicano. Así, formuló una alternativa reformista con la que movilizar a los trabajadores en un mo-

\footnotetext{
27 Burdiel, 2013, p. 214.

28 Romeo, 2000, p. 30.

29 Romeo, 2007, pp. 86-87.

30 Zurita, 2014, p. 345.

31 Sierra, 2010, p. 238.

32 Peña, Sierra y Zurita, 2016.

33 Fernández Sebastián, 2002, p. 559.

34 Barnosell, 2006, pp. 168-178.
} 
mento de enorme competencia política en Barcelona con los moderados y posteriormente con los republicanos ${ }^{35}$. Barnosell ha interpretado que mientras el progresismo consiguió la tolerancia de los sindicatos y radicalizó su discurso para aceptar sus reivindicaciones y otorgarles más oportunidades de representación, las asociaciones obreras inauguraron una larga tradición de apoliticismo que consistía en no comprometerse en actos de oposición abierta al gobierno ${ }^{36}$. Por su lado, Albert Garcia Balañà matiza este apoliticismo en la medida que subraya la relevancia que tuvieron las experiencias políticas de participación de los trabajadores manuales en la milicia o en los cuerpos militares irregulares que apoyaban al progresismo para explicar cómo consiguieron una creciente iniciativa y autonomía al construir significados «obreros», lo que reelaboró el discurso plebeyo ${ }^{37}$.

Este estudio parte de una tipificación sobre las fiestas cívicas en tres categorías distintas que convivieron durante la Revolución Liberal ${ }^{38}$, aunque cada una de ellas tuvo un momento preponderante en el proceso. La primera, la fiesta cívica constitucional, celebraba un nuevo orden político, basado en una legalidad emanada de la soberanía nacional y sancionada por el proceso constituyente o la promulgación de la Constitución. La segunda, la fiesta cívica monárquica, festejaba la transformación pacífica de la institución garante del nuevo orden y de su continuidad dinástica. La tercera, la fiesta cívica insurreccional, representó la exacerbación de la movilización nacional tanto a través de la rememoración de la defensa heroica de las libertades y derechos de los pueblos de España ante la tendencia opresora de la monarquía a concentrar todo el poder político en sus manos como a través de los fracasos o triunfos de los pronunciamientos y revueltas en el devenir de la Revolución Liberal, lo que a menudo - pero no siempre - , convirtió estas fiestas en un acicate de la revolución.

Las fiestas cívicas insurreccionales, mayoritarias durante el Trienio Progresista, pueden ser agrupadas en dos subcategorías: las dedicadas a la rememoración de la represión del régimen liberal moderado que fundamentaron la cohesión sociopolítica del progresismo radical; y las fiestas tributadas a los éxitos de la revolución a través de los pronunciamientos o revueltas populares para acabar con las amenazas que ponían en riesgo la supervivencia del régimen liberal, lo que significaba la reivindicación

\footnotetext{
35 Barnosell, 2011, pp. 96-99 y Barnosell, 2006, pp. 182.

36 Barnosell, 2009, p. 241.

37 Garcia Balañà, 2014, pp. 220 y 251.

38 Roca Vernet, 2016.
} 
de una interpretación del ejercicio de la soberanía nacional en clave popular y local en detrimento de unas instituciones nacionales distantes y distanciadas de la ciudadanía. Cabe tener en cuenta la dificultad del análisis de las fiestas consagradas a las victorias contra el carlismo, que serán interpretadas y reinterpretadas en distintos sentidos, aunque el progresismo lo hará como un éxito revolucionario, de ahí que las incluyamos en esta subcategoría. Por otro lado, las fiestas cívicas constitucionales tuvieron menor proyección que en las etapas precedentes del régimen liberal, aunque se establecerán notables diferencias en la celebración de la Constitución de 1837 entre Barcelona y otras ciudades españolas. En último lugar se analizan las fiestas de la Sociedad Mutua de Tejedores en las que enfatizará el contenido cívico o político en el ritual festivo, y se observará cómo representó una comunión política entre las autoridades progresistas y los trabajadores, afianzando la base social del progresismo radical.

Todas las fiestas cívicas fueron organizadas por el ayuntamiento constitucional de Barcelona, excepto las de la Sociedad, aunque los representantes municipales tuvieron un lugar destacado en el ceremonial. El estudio de todas las fiestas demostrará cómo se convirtieron en un espacio de construcción en el que se fraguó el progresismo radical popular, negociando una cultura reivindicativa y un imaginario común con el progresismo.

\section{Fiestas cívicas insurreccionales dedicadas a la represión}

Las celebraciones más usuales fueron las que homenajeaban a los mártires o a los héroes de los pronunciamientos, exitosos o fallidos, desencadenados entre 1837 y 1840, convirtiéndolas en fiestas cívicas. La más recurrente en Barcelona fue el homenaje a la memoria de los muertos en la bullanga o, como lo denominaban algunos liberales, pronunciamiento fallido ${ }^{39}$ del 4 de mayo de 1837 . Aquella insurrección estuvo liderada por los milicianos del batallón de la blusa - llamados así por su atuendo típico de los trabajadores de oficio-, que habían sido depurados unos meses antes de la milicia por el capitán general interino, Francisco Serrano, con el apoyo de los sectores conservadores de la ciudad con el

${ }^{39}$ El Constitucional (Barcelona), 5 de mayo de 1842, p. 1; El Constitucional (Barcelona), 4 de mayo de 1843 , p. 1. 
fin de facilitar así la restitución del consistorio municipal de la etapa del Estatuto Real. La bullanga acabó con veintiún milicianos muertos y casi un centenar de heridos, y con la ejecución al cabo de pocos días del republicano Ramon Xaudaró ${ }^{40}$, considerado el instigador de la revuelta.

La represión contra el progresismo revolucionario llegó a su punto culminante en octubre, cuando llegó a Barcelona el nuevo capitán general, barón de Meer, quien había recibido la orden de suspender la Constitución de 1837 y procesar a la cúpula del partido progresista que había colaborado con los milicianos sublevados. Detuvo a veintiún líderes del partido $\mathrm{y}$, antes de que se produjera ninguna sentencia judicial, los desterró a Canarias o al islote caribeño de Pinos ${ }^{41}$, frente a la isla de Cuba, con la única excepción de Guillem Oliver y de Joan Vilaregut, desterrados a Mallorca y Sallent respectivamente a causa de su delicado estado de salud. Algunos de los encausados menos destacados consiguieron huir, como Josep Oriol Ronquillo o Pere Felip Monlau, pero la mayoría llenaron las prisiones. Barcelona no fue la única ciudad catalana que sufrió la represión del capitán general, sino que ciudades como Reus o Tarragona también fueron duramente fustigadas por las persecuciones gubernamentales. La experiencia represiva sufrida por los progresistas y sectores populares favoreció la construcción de un universo simbólico común y cohesionó al progresismo en torno a su repulsa ante cualquier acercamiento al moderantismo.

La primera fiesta cívica dedicada en Barcelona a consagrar aquella memoria se celebró apenas inaugurado el Trienio Progresista, el 19 de noviembre de $1840^{42}$, cuando las banderas de los batallones de milicianos disueltos el verano de 1837 fueron trasladadas del ayuntamiento a la Catedral. Aquella fiesta significó la incorporación de la represión sufrida por los milicianos al ceremonial oficial del progresismo local, pues durante la fiesta se inauguró la nueva lápida dedicada a la Constitución de 1837 en el nuevo edificio del ayuntamiento ${ }^{43}$. Poco antes, el 28 de septiembre de 1840, justo después de confirmarse el éxito del pronunciamiento del 1 de septiembre en Madrid, las banderas habían sido liberadas del encarce-

40 Garcia Rovira, 2008, 125-156.

41 Ghanime y Cao, 2013.

42 Arxiu Històric Ciutat de Barcelona (AHCB). Mateu Crespi, Diario de memorias de Barcelona (1820-1849), Año 1843, 19 de noviembre, p. 135; y AHCB. Protocolos, 1D.XXI-16/6.11.3 «Dia 19 de noviembre de $1840 \ldots »$.

${ }^{43}$ Reyero, 2015, p. 86. 
lamiento simbólico que sufrían en la Ciudadela desde el verano del 37, y habían sido depositadas en el Ayuntamiento de Barcelona ${ }^{44}$. Aquellas medidas pretendían rehabilitar a los milicianos represaliados durante los años precedentes y honrar a la milicia como contrapoder al gobierno de la nación.

El 4 de mayo de 1841 el ayuntamiento organizó la celebración del primer aniversario de la fracasada bullanga. Después del funeral en la Catedral desfiló una procesión cívica hasta el cementerio para homenajear la memoria de Xaudaró y la de su abogado, el progresista José María Canalejas. Tras ello, la comitiva se desplazó hasta al cementerio contiguo al Hospital de la Santa Creu donde el republicano Abdó Terradas hizo una alocución en memoria de las víctimas del 4 de mayo, la mayoría milicianos ${ }^{45}$. Al año siguiente (1842) la celebración alcanzó una mayor dimensión y se llevó a cabo en el espacio que separaba la ciudad de la Ciudadela, el paseo de la Explanada, donde se levantó un túmulo a modo de altar para celebrar una misa y homenajear a las víctimas. Después los batallones de la milicia desfilaron «frente de la Lápida de la Constitución ${ }^{46_{»}}$. La fiesta concluyó con la visita de las autoridades municipales y provinciales al cementerio, convertido en lugar de peregrinación desde el año anterior, y con la apertura de una suscripción en el ayuntamiento para auxiliar las familias de las víctimas de la represión.

El Constitucional, principal periódico progresista, dedicó su portada, como ya hiciera en 1841, a conmemorar la efeméride, y la prensa republicana se hizo eco de la peregrinación de más de mil jóvenes al cementerio ${ }^{47}$ donde entonaron la canción republicana La Campana, convirtiendo la ceremonia en una fiesta cívica de carácter revolucionario que despertó el miedo de algunos sectores liberales de orden, tanto moderados como progresistas. Unas semanas después el Jefe Político publicaba un bando en el que se prohibía cantar canciones republicanas como La Campana, cuya letra denunciaba la amenaza represiva que supondría el regreso de

44 AHCB. Mateu Crespi..., Año 1840, 28 de septiembre, p. 116.

45 El Popular (Barcelona), 5 de mayo de 1841, p. 3; AHCB. Protocolos, 1 D. XXI16/7.2.3, «4 de mayo de 1841. Funcion cívico-religiosa....» y AHCB. Mateu Crespi..., Año 1841, 4 de mayo, p. 21.

${ }^{46}$ AHCB. Mateu Crespi..., Año 1842, 5 de mayo, p. 21, «Aniversario del 4 de mayo»; y AHCB. Protocolos, 1D.XXI-17/1.3.1 «Dia 5 de mayo de 1842. Funcion cívica...» y El Constitucional (Barcelona), 5 de mayo de 1842, p. 1.

47 Peyrou, 2002, p. 79 y Barnosell, 1999, 216. 
los moderados al gobierno ${ }^{48}$, haciendo patente la distancia entre el progresismo gubernamental y el radical. La decadencia festiva resultó evidente en $1843^{49}$, cuando el esparterismo triunfador desde el mes de noviembre anterior intentó eliminar la ceremonia y el ayuntamiento de Barcelona no celebró ningún acto a pesar de la demanda de un grupo de ciudadanos al frente del cual estaba el estucador, Benito Lligades ${ }^{50}$. La fiesta quedó así reducida a la liturgia del funeral en la iglesia del Pino y a un homenaje íntimo en el cementerio. El motivo principal de aquella negativa fue el miedo del ayuntamiento a que la fiesta sirviera de acicate para un nuevo estallido revolucionario del progresismo radical y el republicanismo. Aquella fiesta, según Barnosell, se había convertido en la más destacada de la prensa progresista ${ }^{51}$, pero su celebración iba más allá del progresismo y se erigió en un lugar para la construcción cultural e interclasista del progresismo radical, convirtiéndose en un símbolo común de demócratas y republicanos.

La memoria de la represión moderada se erigió en un elemento fundamental de la identidad progresista radical en Cataluña y en Málaga, donde también habían sido represaliados los progresistas ${ }^{52}$, aunque en menor medida. En ambos casos aquellas víctimas habían sido obviadas del debate político sin que el progresismo parlamentario se hiciera eco de ello, más allá de las opiniones del líder progresista catalán Ramon Salvatóo ${ }^{53}$, quien denunció los hechos ante la cámara.

El Sapo y El Mico era el suplemento burlesco del diario El Constitucional e ilustró en su cabecera los elementos que contraponían el imaginario simbólico del progresismo radical y de los moderados: mientras los primeros eran partidarios de la insurrección, del liderazgo social de la revolución y rememoraban la represión moderada centrada en tres espacios (los destierros a Canarias y en Pinos, y el cautiverio en la Ciudadela de Barcelona) así como en el martirio del republicano Xaudaró, los segundos, los moderados, eran partidarios del «orden, la paz, la justicia, [la regente]

48 Barnosell, 1999, 217.

49 AHCB. Mateu Crespi..., Año 1843, 4 de mayo, pp. 45 y El Constitucional (Barcelona), 4 de mayo de 1843, p. 1.

50 AHCB. Protocolos, 1D.XXI-17/2.1 «Respuesta negativa del ayuntamiento a la petición de Juan Alabau y Benito Lligades...».

${ }^{51}$ Barnosell, 2004, pp. 147-150.

52 Lawrence, 2014.

53 Roca Vernet, 2012. 
M. ${ }^{a}$ Cristina, Rebelión de octubre, Estatuto Real, y barón de Meer ${ }^{54}$ ». La publicación no perdía oportunidad para denunciar el sistema represivo impuesto por los moderados, que vulneraba sistemáticamente la Constitución de 1837 y que, amparándose en el estado de excepción, había puesto fin a las libertades individuales y a los derechos de expresión y opinión ${ }^{55}$. También insistía en la necesidad de reparar los daños causados a los progresistas represaliados, por lo que no dudaba en «sacarlo a colación siempre y cuando a mano le venga ${ }^{56} \gg$. El suplemento recordaba reiteradamente a los tejedores que solo aquellos progresistas les garantizaban unas buenas condiciones económicas y sus derechos políticos, mientras que «los que usurparon a los jornaleros todos los derechos políticos y los escluyen de la milicia nacional cuando mandaban ${ }^{57} \gg$ habían sido los moderados.

El semanario adoptaba un estilo humorístico, burlón y caricaturesco a través de las personificaciones de animales para fustigar a su adversario político, el periódico moderado El Papagayo ${ }^{58}$. El Sapo y el Mico personificaban a grupos sociales distintos: mientras el primero se identificaba con las clases populares y los tejedores, levantando el garrote o la porra contra sus enemigos, el segundo representaba a los sectores más acomodados de la ciudad, representándolos empuñando la pistola, el puñal o la espada $^{59}$. Era evidente que el suplemento había sido concebido como un espacio de circulación de ideas e imágenes políticas entre las clases populares y el progresismo, como ponían de relieve todas aquellas referencias que remitían a un universo cultural compartido que llevaría a la cohesión política de un interclasista progresismo radical.

Las principales ciudades españolas durante el Trienio ampliaron las liturgias festivas dedicadas a la consagración de la memoria de la represión monárquica durante la Década Ominosa que se había instaurado en el segundo lustro de los años treinta. De esta forma convirtieron la fecha de la ejecución de los liberales represaliados en una fiesta cívica: en Málaga ${ }^{60}$, el 11 de diciembre de 1842 se erigió un monumento a José María Torri-

54 Suplemento al Constitucional. El Sapo y el Mico (Barcelona), 24 de julio de 1842, p. 1.

55 Supl. El Sapo y el Mico (Barcelona), 23 de octubre de 1842, p. 3.

56 Supl. El Sapo y el Mico (Barcelona), 9 de octubre de 1842, p. 1.

57 Supl. El Sapo y el Mico (Barcelona), 7 de agosto de 1842, p. 1.

58 Guillamet, 1993, pp. 170.

59 Supl. El Sapo y el Mico (Barcelona), 22 de septiembre de 1842, p. 4.

${ }^{60}$ Morales, 2017. 
jos y sus compañeros; en Granada ${ }^{61}$, el 26 de mayo de 1841 se dedicó uno a Mariana Pineda en la plaza homónima; y en Almería ${ }^{62}$ se inmortalizó la memoria de la expedición de los Coloraos con una procesión cívica el 24 de agosto de 1841 . No obstante, la novedad del Trienio fue que en ciudades como Madrid o Cádiz se rememoraron episodios represivos precedentes: en Cádiz las fiestas recordaron el comportamiento heroico del pueblo represaliado por festejar la Constitución de 1812 antes de que las autoridades la proclamaran (10 de marzo de 1820$)^{63}$ y en Madrid rindieron una homenaje público al general Rafael del Riego en la plaza de la Cebada el día que se conmemoraba su ejecución, el 28 de noviembre. La contraposición de la memoria liberal de las principales ciudades españolas con la de Barcelona demuestra que en esta última la rememoración de la represión gubernamental de 1837 dividía al liberalismo, acercaba el progresismo barcelonés a la causa revolucionaria, popular y democrática, y dificultaba la aceptación del régimen de la Constitución de 1837 si no se hacía algún tipo de reformas.

Durante el Bienio Progresista (1854-1856) las Cortes progresistas continuaron incrementando la nómina de beneméritos de la Patria, a los que se consideraba así por haberse enfrentado a los moderados la década precedente, equiparados estos últimos al absolutismo de Fernando VII ${ }^{64}$. Tampoco en aquellos años se restauró la memoria de las víctimas de la dictadura del barón de Meer. Ni tan siquiera se recuperaría la memoria de las ejecuciones de 1844 en la segunda etapa al frente de la capitanía general de Cataluña del barón. La omisión de la represión contra el progresismo radical enmascaraba la división que provocaba entre los liberales y el potencial desestabilizador para el régimen liberal que implicaba su reivindicación, obviando del relato histórico la alternativa democrática e interclasista que constituyó el progresismo radical.

\section{Fiestas cívicas insurreccionales dedicadas al éxito de la revolución}

La celebración de la insurrección barcelonesa del 18 de julio de 1840 se erigió en la fiesta cívica más popular de Barcelona durante aquellos

\footnotetext{
${ }^{61}$ Cobo y Ortega, 2017.

62 Martínez López, 2017.

63 Butrón, 2000, pp. 173.

${ }^{64}$ Garrido, 2013,pp. 266-267.
} 
años, celebrándose en $1841^{65}$ y $1842^{66}$ sin que tuviera una correlación en otras ciudades españolas, más allá de algunas ciudades catalanas. La insurrección o pronunciamiento del 18 de julio estalló estando la regente María Cristina en Barcelona, donde se había trasladado con el pretexto de tomar unos baños para que la reina Isabel recobrara la salud. El objetivo real, sin embargo, era recabar el apoyo del general Espartero que se había desplazado a Cataluña para liquidar los últimos conatos carlistas. Una década después el viaje real fue satirizado por el republicano Anselm Clavé en su zarzuela L'Aplech del Remei, en la que se ensalzaba la respuesta asociativa de las clases populares para oponerse a la decadente nobleza y monarquía, desencadenándose el estallido revolucionario ${ }^{67}$, con lo que se enfatizaba una vez más que el progresismo había articulado un espacio político interclasista y una cultura reivindicativa común que el republicanismo intentaba apropiarse.

La regente quiso aprovechar aquel viaje para sancionar la ley de ayuntamientos que recortaba la autonomía municipal y dejaba en manos del ejecutivo la elección del alcalde ${ }^{68}$. Con ello se pretendía acabar definitivamente con la Revolución Liberal, impidiendo el acceso al poder al liberalismo progresista y radical. A mediados de julio de 1840, durante su estancia en Barcelona, la regente escribió en su diario que la multitud embravecida quería acabar con la familia real y que en el gentío se habían introducido algunos hombres de Espartero que gritaban a favor de su nombramiento como rey ${ }^{69}$, poniendo de relieve la animadversión que sentía la reina madre por el victorioso general. La insurrección no acabó con la familia real pero sí que forzó la dimisión del gobierno de Evaristo Pérez de Castro. La ley de ayuntamientos tampoco llegó a aprobarse. Fue innegable el triunfo de un progresismo popular en Barcelona y cómo este amenazaba la autoridad de la regente, que intentó refugiarse en Valencia. La debilidad de esta, sin embargo, era evidente y el progresismo se alejó de ella depositando su confianza en la popularidad del nuevo héroe, el general Espartero.

${ }^{65}$ Biblioteca de Catalunya (BC). Folletos Bonsoms 18961, «Barceloneses. El dia 18 de julio se acerca...».

${ }^{66}$ BC. Folletos Bonsoms 18931, «Barceloneses...» y BC. Fondo Junta de Comercio, Legajo LXXXVIII, núm. 236-237, «Va á celebrarse el segundo aniversario del 18 de julio de $1840 \ldots »$.

67 Arribas, 2016.

68 Fuster, 2008, p. 55.

69 Burdiel, 2010, p. 62. 
El primer aniversario ${ }^{70}$ de la insurrección del 18 de julio fue oficiado por las autoridades municipales, que la prensa progresista aprovechó para proclamar la apertura de la celebración a todos los liberales y explicitar la invitación a los moderados ${ }^{71}$. Sin embargo, ninguno de estos asistió, pues la celebración fue interpretada como el «precursor del pronunciamiento de setiembre ${ }^{72} \gg$, demostrando así la incapacidad del progresismo para arrastrar al moderantismo hacia los nuevos símbolos y mitos de la Revolución Liberal, exclusivamente capitalizados por el progresismo. La celebración de aquel primer aniversario reunió a progresistas, demócratas y republicanos, y en el banquete ofrecido a los concejales que en 1840 habían desafiado a la regente, uno de los protagonistas fue el republicano Terradas, «quien brindó a la tolerancia absoluta de todas las opiniones y creencias, como elemento vital del órden y progreso $^{73} \gg$.

La prensa progresista destacó el poco entusiasmo que despertaba el segundo aniversario de la fiesta (1842), pues ninguno de los objetivos de la revolución del 18 de julio y del 1 de septiembre de 1840 se habían conseguido y, por el contrario, se habían «vuelto a ver estados de sitio, disoluciones de la milicia, de ayuntamientos; ministerios anti-constitucionales infractores de las leyes». Por lo tanto, la revolución no había dado «más libertad, ni mas goces materiales sirviendo tan solo para el medro, fortuna y engrandecimiento de unos cuantos corifeos que ahora habian ${ }^{74} \gg$. El artículo corroboraba el desencanto que los gobiernos progresistas habían suscitado entre las filas del progresismo radical, alejándolo de la política parlamentaria y ratificando así su proyección insurreccional como única vía de acceso de la ciudadanía al poder político. Aquel desencanto popular fue aprovechado por la prensa moderada ${ }^{75}$ para proyectar una imagen de poca adhesión popular a la fiesta, aunque la concurrencia fuera significativamente relevante, como afirmaban algunos periódicos próximos al progresismo de notables ${ }^{76}$.

70 AHCB. Mateu Crespi,..., Año 1841, 18 de julio, pp. 38-40 y AHCB. Protocolos, 1D.XXI-17/1.3.2. «Dia 18 de julio de $1842 \ldots »$.

${ }^{71}$ El Constitucional (Barcelona), 18 de julio de 1841, p. 1-3.

72 El Guardia Nacional, [El Nacional] (Barcelona), 18 de julio de 1841, p. 2.

73 El Popular (Barcelona), 21 de julio de 1841, p. 3.

74 El Constitucional (Barcelona), 19 de julio de 1842, pp. 2-3.

75 Lecuyer, 1999-2000, p. 155.

76 Eco del Comercio (Madrid), 24 de julio de 1842, p. 1. 
En 1843 la fiesta no se celebró, ya que un mes y medio antes había estallado un nuevo pronunciamiento en Barcelona contra el regente Espartero liderado por progresistas radicales y republicanos que constituyeron una junta revolucionaria que se sumó al pronunciamiento de Málaga que se extendía por Andalucía, el Levante y Galicia. La anti-fiesta se manifestó cuando el 20 de julio de 1843 un grupo de ciudadanos se reunió en la plaza de la Constitución para demostrar su disconformidad con aquella omisión, «profiriendo voces de Abajo la Junta, la Diputación y el Ayuntamiento ${ }^{77} \gg$. Aquel verano se había invertido la situación: mientras el gobierno local estaba en manos del progresismo democrático, el esparterismo se echaba a la calle.

El triunfo del pronunciamiento del 1 de septiembre de 1840 se celebró en Barcelona tres semanas después, el día 24, cuando la milicia nacional despidió al general Espartero ${ }^{78}$ que se dirigía a Madrid, y cinco días después se celebró en Madrid, cuando se supo que el general sería el nuevo presidente del Consejo de Ministros. La mayoría de las ciudades de la monarquía esperaron al nombramiento del general como regente para celebrar el triunfo de la revolución de septiembre, como en Cádiz ${ }^{79}$, Sevilla $^{80}$, Zaragoza $^{81}$, Valencia ${ }^{82}$, Vinaroz ${ }^{83}$, etc. No ocurrió así en Barcelona, donde el ayuntamiento mostró su disconformidad no iluminando los principales edificios públicos para homenajear el triunfo de la regencia única en detrimento de la tripartita ${ }^{84}$. Esto ponía de relieve el descontento del progresismo con la opción escogida por las Cortes ante el estado de excepción que sufría Barcelona desde el mes de julio precedente y la prohibición de las sociedades patrióticas, lugares esenciales de la articulación interclasista de la alternativa progresista ${ }^{85}$. Aquellas fiestas cívicas tuvieron un elemento en común: la presencia del retrato del regente junto al de reina niña, lo que convirtió a Espartero en extremadamente popular. Todas las fiestas cívicas en España celebradas entre diciembre de 1840 y septiembre de 1841 llevaron en procesión el retrato del duque de la Vic-

\footnotetext{
77 AHCB, Mateu Crespi..., año 1843, 20 de julio, p. 108.

78 AHCB, Mateu Crespi..., año 1840, 24 de septiembre, p. 113.

79 Eco del Comercio (Madrid), 4 de enero de 1841, p. 4.

${ }^{80}$ Reyero, 2013,pp. 701-714.

81 El Constitucional (Barcelona), 11 de junio de 1841, p. 1.

82 Eco del Comercio (Madrid), 21 de mayo de 1841, p. 3.

${ }^{83}$ Lecuyer, 1999-2000, p. 59.

${ }^{84}$ El Popular (Barcelona), 15 de mayo de 1841, p. 3.

85 Barnosell, 2006.
} 
toria, lo que corroboraría cómo se promovió su culto popular, sacralizándolo al ponerlo al lado y al mismo nivel que la reina a la vez que, como ha explicado A. Shubert ${ }^{86}$, se enaltecerían hasta la saciedad los orígenes plebeyos del regente.

La fiesta del 1. ${ }^{\circ}$ de septiembre solo se festejó en Barcelona en 1841 y si comparamos las opiniones aparecidas en la prensa sobre las fiestas cívicas barcelonesas constatamos que aquella celebración tuvo menor repercusión que la del 18 de julio o la dedicada al 4 de mayo, y solo se festejó en una ocasión en $1841^{87}$. Aun así, se publicó el deseo del ayuntamiento de que la fiesta se convirtiera en fiesta nacional ${ }^{88}$, como reclamaba una mayoría de diputados en Cortes. Durante la celebración del $1 .^{\circ}$ de septiembre, el acalde demócrata Pere Mata ${ }^{89}$ anunció la apertura de catorce escuelas gratuitas para niños y niñas, con lo que se quería reforzar la imagen de un progresismo radical comprometido con la mejora de las condiciones de las clases populares en las que confiaba para la construcción de un futuro democrático ${ }^{90}$. El progresismo radical celebraba la regencia de Espartero pero intentaba seguir cultivando su proyecto político reformista e interclasista.

En Barcelona el esparterismo, identificado con la revolución septembrina, se debilitó rápidamente al limitar los espacios preminentes del desarrollo radical del progresismo entre las clases populares, como eran la milicia, las sociedades patrióticas y las sociedades obreras. El Popular, periódico demócrata en el que escribía Mata, publicó en sus páginas que la fiesta debía celebrarse, pero recordaba que el pronunciamiento era la última de las decepciones de un liberalismo revolucionario que no conseguía «afianzar las libertades populares, ni realizar todas las consecuencias de la soberanía nacional tantas veces proclamada en $v^{2}{ }^{91}{ } \gg$. La fiesta se celebró en otras ciudades catalanas ${ }^{92}$ y españolas ${ }^{93}$. Sin embargo, en ciudades como Madrid, la discrepancia alrededor de la fiesta y sobre cuál era

86 Shubert, 2015.

${ }^{87}$ BC. Folletos Bonsoms 18977, «A los habitantes de esta capital...».

${ }_{88}$ Eco del Comercio (Madrid), 10 de septiembre de 1841, p. 1-2.

${ }^{89}$ El Constitucional (Barcelona), 10 de septiembre de 1841, pp. 1-4.

${ }^{90}$ El Correo Nacional. Continuación del primitivo Español (Madrid), 31 de agosto de 1841, p. 1.

91 El Popular (Barcelona), 1 de setiembre de 1841, p. 3.

92 Eco del Comercio (Madrid), 10 de septiembre de 1841, p. 1-2; y El Constitucional (Barcelona), 4 de septiembre de 1841, p. 3.

${ }^{93}$ Eco del Comercio (Madrid), 28 de septiembre de 1841, p. 1. 
su apoyo real entre los madrileños fue un elemento de discusión constante ya desde el primer aniversario. La prensa moderada se preguntaba « ¿Porqué Madrid era ayer un cementerio de soledad? ${ }^{94} »$, y los progresistas respondían afirmando que había una «inmensa concurrencia de gentes por todas las calles ${ }^{95}$ », lo que corroboraba la importancia que daban unos y otros a la popularidad de las fiestas cívicas.

La capital de la monarquía fue el principal baluarte del esparterismo, como apunta Javier Pérez Núñez, y la fiesta devino muy popular, celebrándose todos los años del Trienio ${ }^{96}$, demostrando así que el progresismo mantenía una relación privilegiada con los sectores populares, que articulaban su identidad política casi exclusivamente alrededor de la milicia nacional. Esto les aproximaba al esparterismo, siguiendo un modelo que tenía ciertas similitudes con el bonapartismo popular francés. Aun así, en Madrid la fiesta del $1 .^{\circ}$ de septiembre fue resignificada continuamente, a diferencia de lo que ocurrió en Barcelona donde desapareció como referente, probablemente porque estuvo asociada a la versión más intervencionista y represora del regente. Así, en 1842 la diputación madrileña intentó instrumentalizar la fiesta para «superar la profunda división de las filas del progresismo» y al año siguiente, después de la huida de Espartero, el ayuntamiento madrileño interpretó la fiesta como un relanzamiento del pronunciamiento de 1840. Aunque aquel año (1843) la fiesta fue menos espléndida que en años anteriores y no contó con la presencia de la milicia, sí demostró que la fiesta podía ser aceptada momentáneamente por el nuevo orden político moderado-progresista ${ }^{97}$.

Nada que ver con lo que sucedía en Barcelona en aquellos años. En 1842 algunos progresistas se quejaban de la ausencia de la celebración y responsabilizaban de ello al consistorio municipal. El 1 de septiembre de 1843 sí que hubo fiesta en Barcelona, aunque el motivo era la presencia en la ciudad del general Juan Prim, enviado por el gobierno antiesparterista, pero evidentemente no se rememoró el pronunciamiento de 1840 . La fiesta se limitó a una concentración multitudinaria en la plaza de la

${ }^{94}$ El Guardia Nacional, [El Nacional] (Barcelona), 10 de septiembre de 1841, p. 4.

95 Eco del Comercio (Madrid), 2 de setiembre de 1841, p. 2.

96 Pérez Núñez (2015): 18; Eco del Comercio (Madrid), 1 de septiembre de 1841; El Correo Nacional. Continuación del primitivo Español (Madrid), 2 de septiembre de 1841, p. 3; El Constitucional (Barcelona), 6 de septiembre de 1841, p. 1; y El Constitucional (Barcelona), 9 de septiembre de 1841, p. 1.

97 Pérez Núñez, 2015, p. 18. 
Constitución y al discurso del general desde el balcón del ayuntamiento, interrumpido en varias ocasiones por los gritos de la multitud a favor de la Junta Central ${ }^{98}$ y de desafío al gobierno, todo lo contrario de lo que ocurría en Madrid. La fiesta cívica de Barcelona resultó ser una expresión del ambiente desafiante «centralista» de los partidarios de la Junta Central, que con la manifestación querían convencer al general Prim de que la ciudadanía y las autoridades electas, y no el gobierno, eran la auténtica representación de la nación.

El descrédito gubernamental se había extendido entre el liberalismo revolucionario desde los años del Trienio Liberal, cuando se habían convertido en habituales los enfrentamientos entre un liberalismo popular radicalizado, liderado primero por exaltados, y el gobierno. Prueba del liderazgo político que ejercía el progresismo radical en el devenir político de la nación fue la opinión del diario progresista El Constitucional, que afirmaba orgullosamente que el pueblo de Barcelona había derrocado a dos gobiernos, reivindicando así su espíritu insurreccional y reclamando para él la gratitud de las Cortes que menospreciaban aquellas acciones y no les ofrecía ningún reconocimiento, a diferencia de lo que había sucedido con otras ciudades antiesparteristas como Valencia. De ahí que el progresismo arremetiera de nuevo amenazadoramente contra el gobierno, recordándole que «el pueblo barcelonés encumbró a Espartero, y este le bombardeó; el gobierno que manda en Madrid acaba de ser encumbrado por el pueblo barcelonés, y también este le desprecia ya ${ }^{99}{ } \gg$.

Con la nueva etapa liberal progresista se abrió de nuevo el debate sobre qué fecha debía instituirse como nueva fiesta nacional. Durante el primer aniversario del pronunciamiento del $1 .^{\circ}$ de septiembre de 1840 el ayuntamiento de Madrid hizo una petición a las Cortes para declarar aquella fiesta cívica como fiesta nacional ${ }^{100}$, sustituyendo la dedicada a la promulgación de la Constitución de 1837, sin que las Cortes llegaran a aprobarla a pesar de que la discusión se alargara durante meses. La prensa madrileña protagonizó un tenso debate sobre la conveniencia del cambio de fecha ${ }^{101}$, pues el moderantismo consideró que el pronunciamiento de septiembre enaltecía la división entre los españoles, por lo que proponía otras fechas alternativas que representaran mejor la unidad nacional,

\footnotetext{
98 AHCB. Mateu Crespi..., Año 1843, 1 de septiembre, p. 125.

99 El Constitucional (Barcelona), 2 de septiembre de 1843, p. 3.

100 Diario de Madrid, 31 de agosto de 1841, p. 1.

101 Lecuyer, 1999-2000, p. 58.
} 
como eran la firma del convenio de Vergara, el acuerdo de amnistía de la regente María Cristina o la decisión de la regente de reabrir las Cortes después de diez años cerradas ${ }^{102}$.

\section{Fiestas cívicas insurreccionales dedicadas a las victorias contra los carlistas}

Durante el Trienio Progresista se celebraron fiestas cívicas asociadas a los triunfos de los liberales contra los carlistas, interpretadas como el triunfo de la revolución frente a sus adversarios. Sin duda la más popular fue la «Cinco marzada» que rememoraba la victoria de los zaragozanos ante las tropas del pretendiente Carlos María Isidro de Borbón el 5 de marzo de $1838^{103}$. La fiesta se conmemoró durante los años del Trienio ${ }^{104}$, dedicándole el semanario romántico progresista La Aurora numerosos artículos en aquellos años ${ }^{105}$, y fue erigida en nacional al reivindicar su contenido liberal ${ }^{106}$. Otras localidades también continuaron celebrando las victorias ante los asedios carlistas, como ocurrió en Gaibiel ${ }^{107}$ (Castellón, 18 de julio de 1841), Oviedo (23 de octubre de $1841^{108}$ ), Requena (Valencia, 2 de mayo de $1841^{109}$ ), Berga (Barcelona, 4 julio de $1841^{110}$ ) u Hospitalet de Llobregat (Barcelona, 23 de julio 1841111).

La fiesta dedicada a la firma del convenio de Vergara, el 31 de agosto de 1839, como demuestra Garrido, se extendió por toda la geografía española las primeras semanas de septiembre de $1839^{112}$, aunque no gozó del consenso necesario para perpetuarse en los años posteriores en la medida

102 Por haber sido denunciando. La Posdata (Madrid), 1 de abril de 1842, pp. 1-2.
103 Lecuyer, $1999-2000$, p. 59.
104 Mayoral, 2013.
105 Agudo, 2008, p. 87 .
106 El Constitucional (Barcelona), 18 de marzo de 1841, p. 1. Tercer aniversario. 5 de marzo de 1838 .

${ }_{107}$ El Correo Nacional. Continuación del primitivo Español (Madrid), 18 de julio de 1841, p. 1; y El Guardia Nacional, [El Nacional] (Barcelona), 25 de julio de 1841, p. 1.

108 Agradezco a Christian Demange que me facilitara la consulta de su trabajo inédito expuesto en la Journée d'étude Deuils polítiques en France et en Espagne au XIX siècle, Université Stendhal-Grenoble 3, el 30 de enero de 2015.

109 Ibídem.

110 El Constitucional (Barcelona), 14 de julio de 1841, pp. 1-3.

111 El Constitucional (Barcelona), 22 de julio de 1841, p. 4.

112 Garrido, 2012, pp. 16-23. 
que el moderantismo quiso contraponerla a la fiesta del $1 .^{\circ}$ de septiembre. En ciudades como Barcelona, donde se celebró en 1839 y 1840, se erigió en un exaltación del culto al general Espartero, sobre todo en 1840, cuando este ya había desafiado a la regente M. ${ }^{a}$ Cristina al apoyar unas semanas antes la insurrección barcelonesa del 18 de julio, por lo que la fiesta se asoció a la unidad del progresismo revolucionario en torno al general. De este modo se colgó en la casas consistoriales el retrato de la niña reina, el del presidente republicano George Washington ${ }^{113}$ y el del general Espartero quien, como el general norteamericano, se erigía en el principal defensor de la libertad e independencia de España.

Mientras la fiesta se identificó con el general Espartero, los progresistas se sumaron a ella, pero rápidamente, a partir de 1841, el moderantismo consiguió resignificar el convenio de Vergara. Esto provocó que ni en Madrid ni en Barcelona se celebrara su segundo aniversario ${ }^{114}$, pues la conmemoración se interpretaba como la continuidad de la dinastía, el afianzamiento de la libertad y la conciliación entre los partidos ${ }^{115}$, contraponiéndola a la dedicada a la revolución del $10^{\circ}$ de septiembre que debía celebrarse dos días después y ensalzaría la figura del general liberador. Aun así, la fiesta mantuvo una la pluralidad de significados, como lo demuestra que en 1843 todavía sirviera para que el consistorio de A Coruña reivindicara la fidelidad de la ciudad al regente Espartero ante el pronunciamiento antiesparterista del mes de junio anterior ${ }^{116}$. Las fiestas cívicas dedicadas a la guerra carlista se asociaron a menudo al progresismo esparterista, pues supuso la entronización de Espartero como héroe del pueblo y a la vez permitió enaltecer el comportamiento cívico de las unidades militares irregulares como la milicia o los cuerpos de voluntarios que defendían el régimen liberal como un acto de compromiso político con la revolución.

La ciudad de Málaga se pronunció el 30 de mayo de 1843 contra el regente y así se sumaban al pronunciamiento el coronel Joan Prim y el capitán Llorenç Milans del Bosch en Reus, mostrándose favorables al programa de Joaquín María López ${ }^{117}$. El pronunciamiento alcanzó Barcelona el 9 de junio de 1843 a través del general José Cortinez, lo que más que

\footnotetext{
113 Corrales, 2014, p. 602.

114 Por haber sido denunciando. La Posdata (Madrid), 31 de agosto de 1842, pp. 1-2.

115 El Heraldo (Madrid), 31 de agosto de 1842.

116 El Católico (Madrid), 30 de agosto de 1843, p. 370.

117 AHCB. Mateu Crespi..., Año 1843, 30 de mayo, p. 54
} 
una insurrección desencadenó una fiesta cívica ${ }^{118}$. Un mes después, con la derrota de las tropas de Espartero en Torrejón de Ardoz, el 27 de julio, se acababa virtualmente la regencia del general, lo que se celebró en Barcelona con un desfile de la tropa y la milicia ${ }^{119}$. El triunfo sobre Espartero no trajo la convocatoria de la Junta Central como había prometido J.M. López sino la convocatoria de Cortes y la conculcación del orden constitucional, por lo que Barcelona radicalizó su postura y lideró una nueva ola revolucionaria a la que se añadieron algunas de las principales ciudades como Sevilla, Vigo, Granada, León o Valladolid ${ }^{120}$.

Barcelona durante el Trienio se convirtió en la representación de la insurrección nacional permanente, celebrada en incontables fiestas cívicas que desafiaban a regentes y gobiernos sucesivos, lo que acrecentó la sensación de que el progresismo radicalizado amenazaba el nuevo orden social y el régimen liberal basado en la vilipendiada Constitución de 1837, aunque solo podía hacerse con el control de las instituciones si establecía un nuevo proceso constituyente a través de una revolución juntista, estableciendo una Junta Central. La reivindicación del insurreccionalismo permanente había sido una reacción a la imposición permanente de los estados de excepción, que impermeabilizó el espacio público de cualquier protesta o acción progresista e impidió que el progresismo se proyectara políticamente por cauces legales. El éxito del progresismo radical en la política municipal reforzó sus aspiraciones de asaltar el centro político de la monarquía apelando a la iniciativa revolucionaria de la nación frente al anquilosamiento de las Cortes y sobre todo del gobierno. Por lo tanto, el liderazgo del progresismo radical se arrogó un discurso nacional propio basado en la movilización permanente de la ciudadanía a través de una cultura liberal progresista particular que cohesionó el progresismo radical y atrajo a demócratas, republicanos y los sectores populares.

\section{Fiestas cívicas constitucionales y fiestas monárquicas}

Barcelona careció de fiestas cívicas constitucionales en aquellos años. $\mathrm{Ni}$ siquiera se celebró la entronización de Espartero como regente. El Po-

\footnotetext{
118 AHCB. Mateu Crespi..., año 1843, 9 de junio, pp. 64-65.

119 AHCB. Mateu Crespi..., año 1843, 27 de julio, p. 111.

120 Moliner, 1997, pp. 250-253.
} 
pular, refiriéndose a la omisión de la celebración en 1841 del aniversario de la promulgación de la Constitución de 1837, señaló «la soberana indiferencia con que en Barcelona hemos dejado pasar el aniversario que mas memorable y esplendente debía ser, si en realidad estuviésemos contentos con el código que rije». Aquella fue la primera ocasión durante la Revolución Liberal en que Barcelona no celebraba la fiesta nacional institucionalizada por las Cortes, lo que significó un desafío en toda regla al liderazgo del liberalismo parlamentario, y demostró que la contestación progresista a la Constitución de 1837 fue muy relevante en la capital catalana ya que «la mayoría del pueblo quiere más libertad de la que gozamos ${ }^{121}$ ». El progresismo radical no quiso celebrar la promulgación de aquella norma constitucional pues «no satisfizo a nadie», e hizo hincapié en los continuados estados de excepción que sufría Barcelona, por lo que «apenas ha rejido de hecho un solo dia, sirviendo solo de pretesto al mas feroz despotismo ${ }^{122}$ », lo que enfatizaba el alejamiento entre el progresismo radical y el gubernamental.

Todo lo contrario ocurrió en ciudades como Madrid o Valencia donde se continuó conmemorando el aniversario de la jura y promulgación de la Constitución de $1837^{123}$, y en 1842 alcanzó una gran popularidad en la mayoría de ciudades españolas, cuando el progresismo esparterista buscaba aliados entre algunos moderados para defenderse de las acometidas de los progresistas radicales, republicanos y moderados. La fiesta cívica se celebró el domingo 19 de junio en Valencia, Toledo, Madrid, etc., y la prensa progresista española interpretó la fiesta como una constatación de la popularidad del gobierno ante los numerosos rumores para conformar «un ministerio anti-parlamentario y contrario a las prácticas sancionadas por esta misma constitución ${ }^{124} \gg$. La contrastación entre la realidad barcelonesa que tampoco la celebró y algunas de las principales ciudades españolas demuestra cómo la disconformidad con el marco constitucional devino determinante en la conformación de la popularidad del progresismo radical.

Durante el Trienio Progresista no se celebraron fiestas cívicas monárquicas puesto que, como apunta Carlos Reyero ${ }^{125}$, la celebración institucional del poder monárquico en que se vinculaba al monarca con ri-

\footnotetext{
121 El Popular (Barcelona), 21 de junio 1841, p. 3.

122 Ibidem.

123 Pérez Núñez, 2015, y Frasquet, 2002, p. 98.

124 Eco del Comercio (Madrid), 24 de junio de 1842, p. 1.

125 Reyero, 2015, pp. 131-158.
} 
tuales políticos liberales se produjo tanto antes, con la designación de Isabel como princesa de Asturias y su proclamación como reina, como después, cuando a finales de 1843 se proclamó la mayoría de edad de Isabel. La celebración de la proclamación de Espartero como regente no fue interpretada como una fiesta monárquica, pues se exaltaba la figura heroica del general, vinculándolo a los mitos del liberalismo, como ha destacado Reyero para el caso de Sevilla ${ }^{126}$. En aquellos años se redujo el número de representaciones dedicadas a la reina y a menudo los rituales festivos se asociaron a Espartero, lo que le otorgó a este una popularidad casi regia.

En Barcelona se redujo el número de festejos dedicados a la familia real. Ya no se celebraron las onomásticas ni los aniversarios de la reina madre ni los de la infanta María Luisa Fernanda, y solo se preservó la fiesta de aniversario dedicada a la reina, Isabel $\mathrm{II}^{127}$, aunque ni siquiera fue respetada en 1843 cuando las salvas de artillería fueron sustituidas por las bombas durante el fragor del asedio a la ciudad. El momento más trascendente se produjo en 1842 cuando el ayuntamiento declinó la invitación del capitán general para participar en el besamanos que se celebraba en el palacio real con motivo del cumpleaños de la reina, el 10 de octubre. La negativa del ayuntamiento fue interpretada por la autoridad político-militar como un «desaire y una inobediencia ${ }^{128}$ » a la legalidad constitucional, informando de ello al gobierno. El consistorio municipal respondió que su acción no podía considerarse así pues tenía «bien acreditado que sabe obedecer las leyes y ordenes del gobierno ${ }^{129} \gg$. Con ello el ayuntamiento desafiaba a la monarquía y la distinguía de la nación y de su gobierno, con lo que quedaba patente que la monarquía estaba siendo excluida de la cultura simbólica del progresismo radical, rompiendo la continuidad histórica que la monarquía había querido otorgar a la nación a cambio de garantizarse la continuidad dinástica. El caso de Barcelona probablemente no fue único, pero carecemos de estudios para compararlo más allá de los trabajos sobre Madrid ${ }^{130}$.

126 Reyero, 2013, p. 708.

127 Roca Vernet, 2018.

128 AHCB. Protocolos, 1D.XXI-17/1.2.2 «Ceremonial de Cumpleaños. Barcelona 15 de octubre de $1842 »$.

129 AHCB. Protocolos, 1D.XXI-17/1.2.2 (3) «Carta del Ayuntamiento al Excmo. Sr. Capitán general de cite Excmo Principado. 9 de noviembre de 1842».

130 Luengo, 2013, y Pérez Núñez, 2015. 
Después del pronunciamiento moderado del 1 de diciembre de $1843^{131}$ en que se proclamó la mayoría de edad de la reina Isabel II, esta fecha se festejó en Barcelona con las formas rituales más tradicionales. De nuevo la monarquía adquiría pasado y futuro, eliminando los aspectos más liberales de la ceremonia, mientras que en otras ciudades como en Madrid no fue $\operatorname{asi}^{132}$ y persistieron elementos de continuidad con la regencia de Espartero, sin que se manifestara un claro giro hacia el moderantismo hasta unos meses después. Así se evidenciaban las diferencias entre un progresismo de notables pero con un fuerte arraigo popular, que no impugnaba el liderazgo político de la monarquía borbónica ${ }^{133}$, y el progresismo radicalizado, que amenazaba la supervivencia de la monarquía como agente político.

\section{Fiesta cívica de los trabajadores o fiesta democrática.}

La fiesta de la Asociación o Sociedad Mutua de Tejedores, denominada «democrática» por la prensa progresista democrática ${ }^{134}$ ha sido analizada por el hispanista Michel Ralle, quien ha puesto de relieve que aquel modelo de fiesta tuvo su origen en la presencia de obreros en los banquetes con progresistas y demócratas y se extendió por otras ciudades catalanas como Igualada o Vic ${ }^{135}$. También Barnosell ha estudiado la fiesta para dirimir qué relación tuvo la Sociedad con las autoridades locales y gubernamentales, así como con el progresismo barcelonés ${ }^{136}$. En Barcelona se celebraron entre 1841 y 1843 las fiestas «democráticas» para festejar el aniversario de la fundación de la Sociedad de Tejedores, organización obrera que defendía las reivindicaciones laborales de sus socios. El ritual festivo adaptaba algunos elementos de las fiestas cívicas: transformaban los desfiles de militares y milicianos en procesiones de los socios que llevaban los pendones de las fábricas de procedencia, y los bailes en las plazas y los banquetes se sustituían por una peregrinación a la fuente de en Xirot, en la falda de la montaña de Montjuïc, que acababa en una

\footnotetext{
131 BC. Folletos Bonsoms 18928, «Habitantes de Barcelona...».

132 Luengo, 2013, p. 149.

133 Burdiel, 2010, 140.

134 El Popular (Barcelona), 11 de mayo de 1841, p. 3.

135 Ralle, 1999-2000, pp. 76-77.

136 Barnosell, 1999, pp. 179 y 235.
} 
merienda popular. Las autoridades municipales asistieron con todo el decoro y ceremonial institucional a la tercera edición de la fiesta $(1843)^{137}$, a diferencia de las ediciones precedentes en la que solo había una representación. Así pues, para Barnosell la fiesta se convirtió en la expresión del apoyo del progresismo «avanzado» a la asociación de trabajadores. En la merienda popular concurrían socios y socias con sus familias, jornaleros de otras sociedades ${ }^{138}$ y demás clases de ciudadanos. Todos ellos bailaban y cantaban canciones patrióticas, el himno de Riego y el de Luchana ${ }^{139}$, a pesar de que en la convocatoria se insistiera en el carácter apolítico de la fiesta. Al caer la noche regresaban a la ciudad con orden y sosiego como demostración de su comportamiento cívico.

Las distintas ediciones de la fiesta fueron muy populares y en 1841 la prensa demócrata contrapuso el éxito de la fiesta «democrática» al fracaso que había supuesto la fiesta dedicada a celebrar la proclamación de Espartero como regente ${ }^{140}$. Como ha dicho Barnosell, la Sociedad era la única organización más allá de la milicia que podía movilizar a las clases populares $^{141}$. La fiesta devino junto a la milicia, la sociedad patriótica o la prensa, un espacio preferente en el que se proyectó el progresismo radical, fomentando que tejedores y demás trabajadores compartieran un universo simbólico común que representaba una exaltación del culto a la soberanía nacional en el espacio público local. Como apunta Román Miguel, la desconfianza hacia las instituciones nacionales acercó paulatinamente a los trabajadores y progresistas al republicanismo ${ }^{142}$. La fiesta se erigió en un espacio de representación de la negociación entre trabajadores y progresistas, convirtiéndose en un lugar de significado eminentemente obrero que adoptaba una liturgia cívica con contenido político. Por lo tanto, la fiesta demostraría cómo el progresismo radical reconocía y protegía las sociedades obreras con el fin de garantizarse su apoyo, aunque estas, como afirma Barnosell ${ }^{143}$, inauguraran una larga tradición de apoliticismo. Cabe tener en cuenta que sus afiliados participaron activamente en

137 El Constitucional (Barcelona), 9 de mayo de 1843, pp. 1-3; y Ralle, 1999-2000, p. 77.

138 El Constitucional (Barcelona), 8 de mayo de 1842, p. 2.

139 El Popular (Barcelona), 14 de mayo de 1841, p. 3; y El Constitucional (Barcelona), 10 de mayo de 1842 , p. 2.

140 El Popular (Barcelona), 15 de mayo de 1841, p. 3.

141 Barnosell, 1999, p. 179.

142 Miguel, 2007, p. 112.

143 Barnosell, 2009, p. 241. 
la construcción cultural del lenguaje simbólico del progresismo radical, lo que facilitó su movilización y su incorporación al proyecto interclasista del progresismo, siendo este quien lideró la oposición al gobierno. Aquella participación en el imaginario político común redundó en el apoyo al progresismo, aunque no siempre se vinculara con el interés por el derecho de sufragio pues el activismo político se proyectaba en las movilizaciones, la Milicia Nacional y las peticiones a las autoridades, como ha explicado Jesús de Felipe ${ }^{144}$. Con el fin del Trienio se tuvo que transformar la fiesta obrera en una fiesta patronal del trabajador dedicada a San Pancracio, el día 13 de mayo, eliminándose el ritual festivo cívico y concentrándose en la ceremonia religiosa que también fue sustancialmente modificada, mostrando los distintos significados del ritual religioso en el que hasta el momento habían participado en pie de igualdad las socias.

Durante el Bienio Progresista se recuperó la fiesta, largamente añorada por los trabajadores porque significaba el reconocimiento legal de sus sociedades, y se restituyó el mismo ritual festivo de las tres primeras celebraciones, como reflejaba la cantidad de panfletos que se publicaron en los meses anteriores a la fiesta. Aquella fue la única fiesta cívica del Trienio Progresista recuperada en el Bienio, demostrando que solo parte del universo cultural del progresismo radical había sobrevivido en las filas del obrerismo todavía aspiraba a conciliar sus demandas sociales con un proyecto liberal revolucionario, aunque el progresismo mayoritariamente lo hubiera olvidado. Mientras tanto, el republicanismo intentaba apropiarse y reformular aquella herencia del progresismo radical. El aniversario de la sociedad se celebró de nuevo en 1855 y en él participaron las demás sociedades de socorros mutuos de la ciudad, así como todas las sociedades de tejedores ${ }^{145}$. Las autoridades municipales y provinciales fueron invitadas pero no asistieron, y la fiesta no alcanzó el éxito de las ediciones precedentes puesto que la desconfianza se había apoderado de las relaciones entre los obreros y las alternativas liberales gubernamentales. Estas alternativas ya no compartían el imaginario del progresismo radical que se había apropiado el republicanismo, y la fiesta debe interpretarse como un intento de recrearlo de nuevo.

La fuente de en Xirot devino un espacio emblemático cargado de significado político para los obreros barceloneses y apenas dos meses des-

144 De Felipe, 2011, pp. 131 y 138.

${ }_{145}$ La Corona de Aragón (Barcelona), 11 de mayo de 1855, p. 3; y Benet y Martí, 1976, p. 694. 
pués así quedó patente, durante la huelga general en el verano de 1855 , cuando el 6 de julio los trabajadores se reunieron en la fuente e hicieron sus propuestas políticas, eligiendo nuevas autoridades políticas, militares y eclesiásticas ${ }^{146}$. La fuente era un espacio de consensos políticos entre obreros y liberales revolucionarios, por lo que devino idóneo para materializar la dimensión política de la huelga, nombrando unas nuevas autoridades liberales. Por aquel entonces, sin embargo, el progresismo había abandonado la alternativa revolucionaria para conquistar las instituciones y el obrerismo se había dividido buscando nuevas propuestas revolucionarias más allá del liberalismo. La fiesta de la Sociedad había configurado la fuente como un espacio político común entre trabajadores y progresistas desde el Trienio Progresista, en los que se negociaba la relación entre ambos. La fiesta y la milicia fueron los únicos espacios en los que se pudo representar una continuidad política de la tradición liberal revolucionaria precedente. La desafección obrera hacia el progresismo llegó a su cenit después de la huelga general, como apunta De Felipe ${ }^{147}$, aunque el análisis de la fiesta rebela que hacía tiempo que no compartían una cultura reivindicativa común. El declive de la fiesta de la Sociedad demostró cómo el sindicalismo obrero había perdido peso en la alternativa política del progresismo después del Trienio Progresista.

$\mathrm{Al}$ año siguiente se celebró por última vez el aniversario de la sociedad aunque solo contó con un oficio religioso y un sermón en honor a San Pancracio al que asistieron las autoridades invitadas por la Sociedad. Tras el fin del Bienio la fiesta cayó de nuevo en el olvido y la merienda campestre fue suspendida. La fiesta «democrática» de la Sociedad de Tejedores devino un lugar de aprendizaje de la política en clave democrática, pues confluía la práctica asociativa de los trabajadores de oficio con la cultura simbólica del progresismo radical, afianzando una alternativa política en la que se integraba el reformismo social. De acuerdo con Barnosell, el progresismo en los primeros cuarenta consiguió una base social interclasista y destacó sobremanera el apoyo del sindicalismo mediante un lenguaje político de clases más radical que el republicano, favoreciendo una alternativa reformista con el fin de movilizar a los trabajadores ${ }^{148}$.

146 La Esperanza (Madrid), 9 de julio de 1855, pp. 3-4; El Genio de la Libertad (Palma), 8 de julio de 1855, p. 3; La Iberia (Madrid), 10 de julio de 1855, p.4; Benet y Martí, 1976, p. 695.

147 De Felipe, 2011, p. 139.

148 Barnosell, 2011, pp. 96-99 y Barnosell, 2006, p. 182. 


\section{Conclusión}

El análisis de las fiestas cívicas durante el Trienio Progresista demuestra cómo se conformó una identidad progresista radical con un proyecto político nacional propio liderado desde Barcelona, que se distinguió tanto del progresismo de notables como del esparterista, impulsados ambos desde Madrid. La identidad de aquel progresismo radical se basó en seis aspectos:

- Primero, en el culto a la insurrección o bullanga como expresión legítima del ejercicio de la soberanía nacional, que las fiestas recogieron celebrando y recreando continuamente la movilización popular en el espacio local y, en consecuencia debilitando la autoridad gubernamental y reforzando la idea de que las instituciones locales eran las únicas capaces de democratizar el régimen, impulsando un nuevo proceso constituyente a través de las juntas y construyendo la nación sin excesivas dependencias vinculadas a la historia de la monarquía.

- Segundo, en la conmemoración de la represión de los gobiernos moderados entre 1837-1839, lo que significaba una deslegitimación del régimen constitucional de 1837 a raíz de los continuos estados de excepción que conllevaban la militarización del orden público y la suspensión de sus garantías en Barcelona. Aquella rememoración simbólica alejó al progresismo revolucionario del de notables, confluyendo con demócratas, obreros y republicanos, quienes sostenían una alternativa progresista radical irreconciliable con el marco constitucional.

- Tercero, en el distanciamiento de las expresiones simbólicas impulsadas por las Cortes para representar la unidad del progresismo, como eran las fiestas nacionales, ya fueran dedicadas a la elección del nuevo regente Espartero o a la promulgación de la Constitución de 1837, o el intento de sustituir esta fiesta por la conmemoración del $1 .^{\circ}$ de septiembre. Aquella fue la primera ocasión en la que las fiestas designadas como nacionales por las Cortes no se celebraron en Barcelona.

- Cuarto, en la degradación simbólica de la monarquía en la construcción de la nación y la despolitización de la reina, a la que se desposeyó de capacidad política, lo que se materializaba en una reducción del boato dedicado a los miembros de la familia real. 
- Quinto, en la minimización de la conmemoración del ejército como agente político revolucionario, siendo sustituido por el homenaje a los cuerpos de voluntarios y a la milicia como defensores del régimen liberal, ya fuera en el campo de batalla o en las ciudades catalanas.

- Y sexto, en el mantenimiento de espacios simbólicos y materiales como la milicia y los cuerpos de voluntarios, las fiestas, las sociedades patrióticas, etc., donde se articulaba la construcción del progresismo radical de base interclasista en la que pudieran tener una presencia relevante los trabajadores de oficio, pudiéndose desarrollar una política basada en el reformismo social.

El progresismo radical tuvo arraigo en las principales ciudades de la costa levantina, algunas capitales castellanas, andaluzas y gallegas, pero no cabe duda de que Barcelona determinó el rumbo de aquella alternativa progresista, liderando su formulación más revolucionaria, antimonárquica, democratizadora y favorable a un desarrollo político de los cuerpos electos. En Barcelona el progresismo radical devino mayoritario, imponiéndose sobre otras alternativas progresistas que tuvieron más recorrido político en la cámara parlamentaria. Aquel progresismo radical, de acuerdo con Barnosell, lideró un proyecto reformista que abandonó el liberalismo utópico para incorporar las aportaciones teóricas procedentes del owenismo y fourierismo que serían complementadas con elementos procedentes de Felicité Robert de Lamennais y del republicanismo francés $^{149}$, pero fue más allá ya que cuestionó la centralidad de la monarquía en la configuración de la nación y reivindicó el liderazgo municipal y provincial para definir la nación y vertebrar el régimen liberal, superando la formulación del constitucionalismo gaditano. Aquel progresismo radical fue el último refugio del liberalismo revolucionario, que había intentado transferir la iniciativa política de la revolución a los órganos de representación políticos más cercanos al ciudadano, convirtiéndolos en auténticos intérpretes de la nación por su origen popular. Esto provocó desde el principio enfrentamientos con los órganos de representación nacional más restringidos y poco permeables a la voluntad nacional expresada a través de las distintas formas de movilización política popular, como la milicia nacional, las sociedades patrióticas o las insurrecciones.

149 Barnosell, 2009, p. 240. 
El progresismo radical no formuló un discurso federal explícito a causa de la vinculación que este tenía con el republicanismo y el rechazo que generaba entre las filas moderadas y progresistas de orden, pero sí fraguó un horizonte nacional que se articulaba en torno del municipalismo y se oponía al desarrollo excesivamente estatista del régimen liberal que tenía un origen en la monarquía borbónica. Aquel progresismo no consiguió articular una alternativa parlamentaria y cada vez quedó más aislado, convirtiéndose en refractario a las Cortes. No obstante, durante el Bienio Progresista, de acuerdo con M.C. Romeo, se configuró una alternativa progresista «avanzada» y demócrata municipalista basada en el carácter político y electivo del cuerpo municipal que le confería la capacidad de representar el interés general de la nación ${ }^{150}$. Detrás de aquella alternativa también estaba la necesidad de reavivar la sociedad civil local que había sido ahogada por el centralismo precedente. Romeo subraya las similitudes de este progresismo con el desarrollo político del liberalismo alemán en el espacio municipal ${ }^{151}$. La propuesta del progresismo radical fracasó en su proyección política nacional pero devino fundamental para la historia de la democracia en España, pues fue en el espacio local donde se desarrolló una democratización de la ciudadanía mucho antes de que se hiciera desde las Cortes u otra institución nacional. La historia de este progresismo radical facilitó que en las dos décadas siguientes sus bases sociales se sintieran atraídas por el federalismo en la medida que devolvía el liderazgo de la construcción nacional a las provincias y municipios en detrimento del monopolio de las Cortes.

\section{Fuentes}

Arxiu Històric Ciutat de Barcelona

Mateu Crespi, Diario de memorias de Barcelona (1820-1849)

Fondo de Protocolos

150 Romeo, 2014, p. 166.

151 Ibidem, p. 159. 


\section{Biblioteca de Catalunya}

Folletos Bonsoms

Fondo Junta de Comercio

Prensa

El Constitucional (Barcelona),

Suplemento al Constitucional. El Sapo y el Mico (Barcelona),

El Popular (Barcelona),

La Corona de Aragón (Barcelona),

El Guardia Nacional, [El Nacional] (Barcelona),

El Genio de la Libertad (Palma de Mallorca),

La Iberia (Madrid),

Eco del Comercio (Madrid),

Por haber sido denunciando. La Posdata (Madrid),

El Heraldo (Madrid),

El Católico (Madrid),

El Correo Nacional. Continuación del primitivo Español (Madrid),

Diario de Madrid (Madrid),

La Esperanza (Madrid),

\section{Bibliografía}

AGUDO, Manuela, El Romanticismo en Aragón (1838-1854). Literatura, prensa y Sociedad, Zaragoza, Prensas Universitarias de Zaragoza, 2008.

ARRIBAS, Albert, «L'Aplec del Remei», o «La Mútua de Socors», en L'Aplec del Remei, Arola Editors / TNC, Tarragona, 2016.

BARNOSELL, Genís, Orígens del sindicalisme català, Eumo, Vic, 1999.

BARNOSELL, Genís, «Consens i revolució. Poble i nació a la Barcelona de la Revolució Liberal, 1835-1843», Barcelona. Quaderns d'Història (10), 2004, pp. 137-170.

BARNOSELL, Genís, «Libertad, igualdad, humanidad. La construcción de la democracia en Cataluña (1839-1843)», en SUÁREZ CORTINA, Manuel (ed.), La Redención del pueblo. La cultura progresista en la España liberal, Servicio de Publicaciones de la Universidad de Cantabria, Santander, 2006, pp. 145-182. 
BARNOSELL, Genís, «¿Un reformismo imposible? Organización obrera y política interclasista (Cataluña, 1820-1856)» en CALATAYUD, Salvador (coord.), Estado y periferias en la España del siglo XIX. Nuevos enfoques, PUV, Valencia, 2009, pp. 217-262.

BARNOSELL, Genís, «Republicanismo, progresismo y sindicalismo en Cataluña durante el Trienio Esparterista (1840-1843)», Historia y Política, (25), 2011, pp. 93-118.

BENET, Josep y MARTÍ, Casimir, Barcelona a mitjan segle XIX. El moviment obrer durant el Bienni Progressista (1854-1856), Curial, Barcelona, 1976.

BURDIEL, Isabel, Isabel II. Una biografía (1830-1904), Taurus, Madrid, 2010.

BURDIEL, Isabel, «Monarquía y nación en la cultura política progresista. La encrucijada de 1854», en GARCÍA MONERRIS, Encarna; MORENO, Mónica y MARCUELLO, Juan Ignacio (eds.), Culturas políticas monárquicas en la España liberal. Discursos, representaciones y prácticas (1808-1902), PUV, Valencia, 2013, pp. 213-232.

BUTRÓN, Gonzalo, «Fiesta y revolución: Las celebraciones políticas en el Cádiz liberal (1812-1837)», en GIL NOVALES, Alberto (ed.), La Revolución liberal, Eds. Del Orto, Madrid, 2000, pp. 159-177.

COBO, Francisco y ORTEGA, María Teresa, «Mariana Pineda», Andalupedia, disponible y última consulta 19/02/2017: http://www.andalupedia.es/p_ termino_detalle.php?id_ter $=15582$

CORRALES, Laura, L'estampa i la primera Guerra Carlina a Catalunya (18331840), [Tesis doctoral inédita], Universitat Autònoma de Barcelona, Barcelona, 2014.

DE FELIPE, Jesús, «La orientación del movimiento obrero hacia el republicanismo en España en el siglo XIX (1840-1860)», Historia y Política (25), 2011, pp. 119-148.

DEMANGE, Christian, El Dos de Mayo. Mito y fiesta nacional (1808-1954), Marcial Pons, Madrid, 2004.

DÍAZ MARÍN, Pedro, «Espartero en entredicho. La ruina de su imagen en las elecciones de 1843», Ayer (72), 2008, pp. 185-214.

DIRCKSEN, Katrina, «Solemnizar el nuevo orden. Las proclamaciones de la Constitución en la Ciudad de México, 1812 y 1820», en HENSEL, Silke (ed.), Constitución, poder y representación. Dimensiones simbólicas del cambio político en la época de la independencia mexicana, IberoamericanaVervuert, Madrid, 2011,pp. 121-155.

FERNÁNDEZ SEBASTIÁN, Javier, «Progresismo», FERNÁNDEZ SEBASTIÁN, Javier y FUENTES, Juan F. (eds.), Diccionario político y social del siglo XIX español, Alianza Editorial, Madrid, 2002, pp. 558-562.

FRASQUET, Ivana, Valencia en la Revolución (1834-1843). Sociabilidad, cultura y ocio, PUV, Valencia, 2002. 
FUENTES, J.F., «La fiesta revolucionaria en el trienio liberal español (18201823)», Historia Social (78), 2014, pp. 43-59.

FUSTER, Joan, «El trienni esparterista: la batalla per eixamplar els límits del sistema», en RISQUES, Manel (dir.), Història de l'Ajuntament de Barcelona de l'ocupació napoleónica a l'actualitat, Enciclopèdia Catalana, Barcelona, 2008, pp. 54-61.

GARCÍA BALAÑ̀̀, Albert, «"El verdadero productor”: Lenguaje y experiencia en la formación de las culturas políticas obreras», en ROMEO, M. ${ }^{\mathrm{a} C}$. y SIERRA, M. a (coords.), La España liberal, 1833-1874, Vol. II, en PÉREZ LEDESMA, Manuel y SAZ, Ismael (dir.), Historia de las culturas políticas en España y América Latina, Marcial Pons Historia y Prensas Universitarias de Zaragoza, Madrid, 2014, pp. 217-252.

GARCIA ROVIRA, Anna M. a, «Ramón Xaudaró: el Marat barcelonés» en PÉREZ LEDESMA, Manuel y BURDIEL, Isabel (coord.), Liberales eminentes, Marcial Pons, Madrid, 2008, pp. 125-156.

GARRIDO, Luis, El nuevo Cid. Espartero, María Cristina y el primer liberalismo español (1834-1840), [Tesis doctoral inédita], Universidad de Cantabria, Santander, 2012.

GARRIDO, Luis, «"Dos naciones en una”. La nación progresiva», en MORALES, Antonio; FUSI, Juan Pablo y DE BLAS, Andrés (coords.), Historia de la nación y del nacionalismo español, Galaxia Gutenberg, Barcelona, 2013, pp. 263-276.

GÉAL, Pierre, «Un siglo de monumentos a la Guerra de la Independencia», en DEMANGE, Christian; GÉAL, Pierre; HOCQUELLET, Richard; MICHONNEAU, Stéphane y SALGUES, Marie (eds.), Sombras de mayo. Mitos y memorias de Guerra de la Independencia en España (1808-1908), Collections de la Casa Velázquez, Madrid, 2007, pp. 135-168.

GHANIME, Albert y CAO, David, Antoni Giberga i el liberalisme progressista a Barcelona durant la minoria d'edat d'Isabel II, Seminari d'Història de Barcelona, Barcelona, 2013.

GUILLAMET, Jaume, La formació de la premsa moderna. Periodisme informatiu, polític $i$ cultural a la Barcelona progressista: 1841-1843, Centre d'Investigació de la Generalitat, Barcelona, 1993.

GUEREÑA, Jean Louis, «Fête Nationale, Fête populaire? Les premières commémorations du 2 Mai (1809-1833)», en AYMES, Jean-René y FERNÁNDEZ SEBASTIÁN, Javier, La imagen de Francia en España (1808-1850), Servicio Editorial Universidad del País Vasco, San Sebastián, 1995, pp. 35-50.

HAZAREESINGH, Sudhir, The Saint-Napoleon: Celebrations of sovereignty in nineteenth-century France, Harvard University Press, Cambridge - Londres, 2004.

HENSEL, Silke, «El significado de los rituales para el orden político: la promulgación de la Constitución de Cádiz en los pueblos de Indios, Oxaca, 1814- 
1820», en HENSEL, Silke (ed.), Constitución, poder y representación. Dimensiones simbólicas del cambio político en la época de la independencia mexicana, Iberoamericana-Vervuert, Madrid, 2011, pp. 157-194.

IHL, Olivier, La fête républicaine, Gallimard, París, 1996.

LAWRENCE, Mark, Spain's First Carlist War, 1833-40, Mcmillan-Palgrave, New York, 2014.

LECUYER, M. C., «Fêtes civiques et libéralisme en Espagne (1812-1843)», Bulletin d'Histoire Contemporaine de l'Espagne (30-31), 1999-2000, pp. 49-66.

LUENGO, Jorge, «Representar la monarquía: festividades en torno a la Reina Niña (1833-1846)», en GARCÍA MONERRIS, Encarna; MORENO, Mónica y MARCUELLO, Juan Ignacio, Culturas políticas monárquicas en la España liberal. Discursos representaciones y prácticas (1808-1902), PUV, Valencia, 2013, pp. 109-129.

MARTÍNEZ, Fernando, «Los coloraos», Andalupedia, disponible y última consulta 19/02/2017: http://www.andalupedia.es/p_termino_detalle.php?id_ ter $=5254$

MAYORAL, Raúl, «Representaciones de la historia en la España contemporánea: conmemoraciones y narrativas de la Cincomarzada Zaragozana (18381874)», en AA.VV. (ed.), Claves del mundo contemporáneo. Debate e investigación. Actas del XI Congreso de la Asociación de Historia Contemporánea, edición digital, Editorial Comares, Granada, 2013.

MAYORAL, Raúl, El cinco de marzo de 1838 en Zaragoza. Aquella memorable jornada, Prensas Universitarias de Zaragoza, Zaragoza, 2014.

MIGUEL, Román, La pasión revolucionaria. Culturas políticas republicanas y movilización popular en la España del siglo XIX, Centro de Estudios Políticos y Constitucionales, Madrid, 2007.

MOLINER, Antoni, Revolución burguesa y movimiento juntero en España, Editorial Milenio, Lleida, 1997.

MOLINER, Antoni, «Las fiestas en la ciudad de Barcelona durante la ocupación napoleónica», Ler História (58), 2010, pp. 137-151.

MORALES, Manuel, «José María Torrijos y Uriarte», Andalupedia, disponible y última consulta 19/02/2017: http://www.andalupedia.es/p_termino_detalle. php?id_ter $=19528$

MUNILLA LACASA, María Lía, Celebrar y governar. Un estudio de las fiestas cívicas en Buenos Aires, 1810-1835, Miño y Dávila Editores, Buenos Aires, 2013.

OSTERHAMMEL, Jürgen, La transformación del mundo. Una historia global del siglo XIX, Crítica, Barcelona, 2015.

PAN-MONTOJO, Juan Luis, «El progresismo isabelino», en SUÁREZ CORTINA, Manuel (ed.). La Redención del pueblo. La cultura progresista en la España liberal, Servicio de Publicaciones de la Universidad de Cantabria, Santander, 2006, pp. 183-208. 
PÉREZ NÚÑEZ, Javier, «La nación desde abajo. Las principales efemèrides políticas en el Madrid del régimen constitucional de 1837», en LUENGO, Félix y MOLINA, Fernando (dir.), Factores de nacionalización en la sociedad española contemporánea, XXI Congreso del Instituto de Historia Social Valentín Foronda. Álava, 17-18-19 junio 2015, Instituto de Historia Social Valentín de Foronda, Vitoria, 2015.

MOLINA, Fernando, «Conmemorar la nación desde abajo. Las celebracions patrióticas del Madrid progressista, 1836-1840», Historia y Política (35), 2016, pp. 177-202.

PEYROU, Florencia, El Republicanismo popular en España 1840-1843, Servicio de publicaciones Universidad de Cádiz, Cádiz, 2002.

RALLE, Michel, «Féte militante: l'espace festif des ouvriers á l'épreuve de l'identité sociale (1850-1920)», Bulletin d'Histoire Contemporaine de l'Espagne (30-31), 1999-2000, pp. 67-82.

REYES, Francisco, «Fiestas, manifestaciones y rituales políticos en el siglo XIX. Un itinerario historiográfico entre Francia y Argentina», en CHATRIOT, Alain (ed.), Política, sociedad instituciones y saberes. Diálogos interdisciplinares e intercontinentales, Ediciones UNL, Santa Fe, 2015.

REYERO, Carlos, «Sevilla y las políticas de propaganda visual durante la regencia de Espartero», Laboratorio de Arte (25), 2013, pp. 701-714.

REYERO, Carlos, Monarquía y Romanticismo. El hechizo de la imagen regia 1829-1873, Siglo XXI, Madrid, 2015.

RISQUES, Manel, El govern civil de Barcelona al segle XIX, Publicacions Abadia de Montserrat, Barcelona, 1995.

ROCA VERNET, Jordi, «Ramón Salvató de Esteve» en AA.VV., Diccionario Biográfico de Parlamentarios espanyoles (1820-1854), Cortes Generales, 2012.

ROCA VERNET, Jordi, «Fiestas cívicas en la Revolución Liberal: entusiasmo y popularidad del régimen», Historia Social (86), 2016, pp. 71-90.

ROCA VERNET, Jordi, «Los nacionalismos banales en la Revolución Liberal a través de las fiestas cívicas», en ARCHILÉS, Ferran y QUIROGA, Alejandro (eds.), Nacionalismo banal, Comares, Granada, 2018 (en prensa).

ROMEO, M. ${ }^{a}$ Cruz, «La cultura política del progresismo: las utopías liberales, una herencia en discusión», Berceo (139), 2000, pp. 9-30.

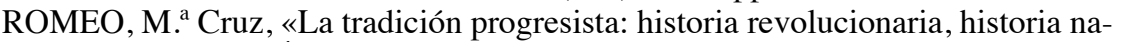
cional», en SUÁREZ CORTINA, Manuel (ed.), La redención del pueblo. La cultura progresista en la España liberal, Universidad de Cantabria, Santander, 2006, pp. 81-113.

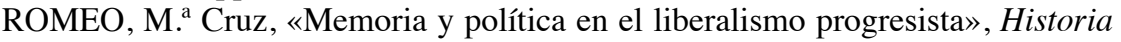
y política: Ideas, procesos y movimientos sociales (17), 2007, pp. 69-88.

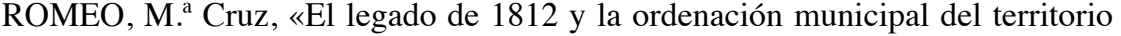
nacional: liberales y demócratas», en BERAMENDI, Justo y VEIGA, Xosé 
Ramón (ed.), Poder y territorio en la España del siglo XIX. De las Cortes de Cádiz a la Restauración, Universidad de Santiago de Compostela, Santiago de Compostela, 2014, pp. 145-172.

SAN NARCISO, David, «Ceremonias de la monarquía isabelina. Un análisis desde la historia cultural», Revista de Historiografía (21), 2014, pp. 191207.

SHUBERT, Adrian, «Being — and staying - Famous in 19th-century Spain: Baldomero Espartero and the birth of political celebrity», Historia y Política (34), 2015, pp. 211-237.

SIERRA, María, «La cultura política en el estudio del liberalismo y sus conceptos de representación», en PÉREZ LEDESMA, Manuel y SIERRA, María (ed.). Culturas políticas: teoría e historia, Institución «Fernando el Católico», Zaragoza, 2010, pp. 233-261.

YAMAMICHI, Yoshiko, «Fiestas y celebraciones cívico-religiosas en la Barcelona constitucional (1820-1823)», Espacio, Tiempo y Forma. Serie V. Historia Contemporánea (15), 2002, pp. 123-155.

ZURITA, Rafael; PEÑA, M. ${ }^{a}$ Antonia y SIERRA, María, «Los artífices de la legislación electoral: una aproximación a la teoría del gobierno representativo en España (1845-1870)», Hispania (223), 2006, pp. 633-670.

ZURITA, Rafael, «El progresismo, héroes e historia de la nación liberal», en ROMEO, M. ${ }^{a}$ Cruz y SIERRA, M. (coords.), La España liberal, 1833-1874, Vol. II, en PÉREZ LEDESMA, Manuel y SAZ, Ismael (dir.), Historia de las culturas políticas en España y América Latina, Marcial Pons Historia y Prensas Universitarias de Zaragoza, Madrid, 2014, pp. 317-346.

\section{Datos del autor}

Profesor asociado en la Universitat de Barcelona (2014-2017), en la Universitat Rovira i Virgili (2015-2017) y profesor colaborador de la Universitat Oberta de Catalunya (2014-2017). Doctor, premio extraordinario y mención europea por la Universitat Autònoma de Barcelona, ha sido investigador postdoctoral en el Instituto Camões (2009), la University of Warwick (2011-2012) y la Universitat Rovira i Virgili (2013-2014). También ha sido profesor asociado en la Universitat Autònoma de Barcelona (2007-2008). Ha publicado dos monografías con sendos premios de investigación: La Barcelona revolucionària i liberal: exaltats, milicians i conspiradors (Premio Jaume Vicens Vives, Institut d'Estudis Catalans, 2011) y Tradició constitucional i història nacional (1808-1823). Llegat i projecció política d'una nissaga catalana: els Papiol (Fundación Ernest Lluch, 2011). También ha publicado más de una docena de artículos en revistas especializadas y más de una veintena de capítulos de libro en editoriales españolas y europeas. 